\title{
Performance Efficiency Measurement In The Nigerian Public Sector: The Federal Universities Dilemma
}

\author{
Ofe Iwiyisi Inua (Ph.D) \\ School of Management Sciences, National Open University of Nigeria \\ Email: ofejobs@yahoo.com \\ Chuks Maduabum (Ph.D) \\ School of Management Sciences, National Open University of Nigeria \\ Email: chuksmaduabum@yahoo.com
}

\section{Doi:10.5901/mjss.2014.v5n20p838}

\section{Abstract}

Concerned by an apparent lack of positive correlationship between investments in federal universities in Nigeria and return on such investments, this study was undertaken. The Data Envelopment Analysis (DEA) was used as an instrument for measuring the performance efficiency of selected broad-based federal universities. Having identified gaps in earlier studies, this study used data from the National Universities Commission (NUC), the main regulatory body of universities in Nigeria. Results reveal that only four (4) (23.5\%) of the 17 federal universities studied can be adjudged as performing efficiently in term of input and output phenomenon. These universities include universities of Maiduguri and Abuja as well as Bayero university, Kano and Nnamdi Azikiwe university Awka. These universities are therefore proposed as benchmarks for other universities in terms of performance efficiency. At the same time, the DEA has again proved to be a useful instrument in the measurement of performance efficiency of institutions.

Keywords: Measurement, Performance efficiency, Data Envelopment Analysis, Federal universities, Decision making unit

\section{Introduction}

The difficulties of input and output measurement in public organizations like federal universities, and the need to focus on management accounting issues such as performance efficiency measurements constitute the stimulant to undertake this study with a focus on Nigerian federal universities. Numerous studies have looked in-depth at the efficiency and productivity of universities (Kempkes and Pohl, 2008; Warning, 2005) in other parts of the world. Measuring efficiency and productivity in federal universities provides an indirect evaluation of public funding management because universities especially federal universities are one of the major users of the nation's resources as they are funded directly by the federal government. Information about federal universities efficiency performance is essential in times of scarce public resources. For instance, knowledge about university performance efficiency enables university management to recognize financial and non-financial shortcomings and improve their performances. In addition, the governments which are responsible for financing federal universities in Nigeria can use efficiency indicators as a guideline for the distribution of funds among the universities and thus create an atmosphere for healthy competition within the federal university system (Kempkes and Pohl, 2008).

Given the importance of efficiency measurement in the education sector, it comes as a surprise that the performance efficiency of universities in Nigeria has not been subjected to sufficient intensive investigation. The study by Abdulkareem and Oyeniran (2011) made an attempt though not empirical in nature. The input and output indicators in universities were mentioned but there was no empirical work carried out on the indicators to show how efficient universities are in Nigeria. Their work also focuses on both financial and non-financial inputs and outputs. Igbinosa (2008) measured the relative efficiency of Nigerian federal universities using the Data Envelopment Analysis (DEA) and results indicated that Nigerian federal universities are technically and allocatively efficient.

However, from the review of existing literature on federal universities, the following gaps exist: there is insufficient empirical evidence on the measure of the extent of performance efficiency of federal universities in Nigeria; there are difficulties of input and output measurement of universities; there is need to identify which of the federal universities are efficient and should be understudied by other universities in Nigeria; there is need to focus on management accounting 
issues such as performance efficiency measurement in federal universities; most of the studies done in Nigeria involve measuring performance of staff (Popoola, Oyinloye \& Oginni, 2011) or a particular section of university education for example webometric ranking (Utulu, 2007).

The purpose of this study therefore is to fill the above stated gaps. Our study is to address the following research questions:

1. What are the inputs and outputs that could be used in measuring the performance efficiency of Federal universities in Nigeria?

2. To what extent are Nigerian federal universities performing efficiently?

3. Which federal university can be regarded as the most efficient using the DEA?

\section{Literature Review}

\subsection{Development of Performance Efficiency Techniques}

Management accounting has had a primary function in developing performance measures to assist managers in planning and controlling their organizations. Modern efficiency performance measurement began with Farrel (1957) who defined the economic efficiency as the ability to obtain maximum output from available resources (technical efficiency and to choose the best package of inputs given their prices and marginal productivities (allocative efficiency). The classical microeconomic theory assumes that firms and institutions operating in a free market exert maximum effort to maximize their profits/minimise their costs and hence operate at $100 \%$ efficiency, that is, they produce maximum output from the given inputs and use the best combination of inputs. However, the evidence from practice does not always support this. Some organizations, especia1ly those operating at non-profit levels, tend to deviate from the predicted behaviour and are hence regarded as inefficient (James, 1990).

Research on the performance and efficiency of organizations has been given enormous attention over the past decades (Thore, Kozmetsky and Phillips, 1994; Hsu and Liu, 2008; Joshi and Singh, 2009). Previous research basically used conventional ratios such as return on equity (Ponnu and Ramthandin, 2008) and return on invested capital (Hsu and Liu, 2008). Later, many studies used various measures of performance which include financial index (Wu, Kao and Cheng, 2006), a non-parametric approach - Data Envelopment Analysis (DEA) (Wu, 2005) and parametric approachStochastic Production Approach (SPA) (Radam and Abdullahi, 2008).

The employment of various types of performance measures has enabled corporations to assess the efficiency and effectiveness of their business processes vis-ã-vis their strategic objectives. Performance measurement tools can help organizations evaluate their resource allocation process in order to determine how resources can be better managed and distributed to the appropriate places (Hannula, Kulamala, and Suomala, 1999; The Steering Committee for the Review of Commonwealth/State Service Provision [SCR], 1997; Wright, Smith, Jesser, and Stupeck, 1999). In measuring performance, the linkages between the resources used and the output generated are clearly established. Identifying the specific relationships between input and output will enable organizations to determine whether the resources have been appropriately allocated to produce the desired outcomes. Furthermore, the qualification of the deficiencies in the performance through the gathering of performance data will enable organizational decision-makers to monitor the organization's performance over time (SCR, 1997).

Efficiency of an organization can be defined as the maximization of a set of output (Output-oriented) given a set of inputs or minimization of a set of inputs (Input-oriented) for a given output (Saranga and Phani, 2004) in a Decision Making Unit (DMU). Bowlin (1998) defined a Decision Making Unit (DMU) as an entity responsible for converting inputs into output. A DMU is a homogeneous entity in the sense that it uses the same resources to produce the same outcomes in varying amounts. For example, university units such as Departments, Faculties, or Colleges are homogenous as they all perform the same tasks but of course differ in their levels of activities and resource usage. The characterization of unit assessment as "decision-making" implies that it has control over the process it employs to convert its resources to outcomes.

Identification of the inputs and the output in assessment of DMUs is very crucial. The inputs should capture all resources which impact on the output. The output should reflect all the useful outcomes on which we wish to assess the DMUs. Furthermore, any environmental factors which impact the transformation of resources into outcomes should be reflected in the inputs or output depending on the direction of the impact. In general terms, the essential idea is that we wish to assess how efficiently each DMU, for instance, university, handles the transformation process. To do this, we must capture in output what the DMU achieves, take into account the resources it uses and allow within the input-output set for any factor beyond the DMUs control which may impact its performance. What is under the DMU control will, in 
general, depend not only on the nature of activity in which a DMU is engaged but also on the decision-making authority it has within the broader framework of its parent organization (Thanassoulis, 2001).

In the private sector, varieties of indices are used to assess performance. These include: profit, rate of return on assets, unit cost and other simple partial productivity measures (Coelli, 1992). It has been argued by researchers, for instance, Bowlin, (1998), Jouimady and Ris (2005), that these are not perfect measures of public sector performance. The profit and return on asset measure may not be a suitable measure of university performance because output prices of research papers and degree courses are not available and if output prices are available, profit maximization is not one of the stated aims of the university (Coelli, 1992). The unit cost and other partial productivity measures are not suitable in this context because universities are multi-input and multi-output organizations and these measures deal with a single output and input.

Furthermore, most indicators are typical of the ambiguity found in education performance measurements, for instance, high degree results may be due to the high entry qualification of the students rather than to effective teaching or any other variable. In fact, it is difficult to capture the interaction among the various input and output in the educational system. This challenge is solved using the Data Envelopment Analysis.

\subsection{The Data Envelopment Analysis}

DEA is a linear programming technique for examining how a particular Decision Making Unit (DMU) or a university in this study operates relative to other universities. The technique creates a frontier set by efficient universities and compares it with inefficient universities to produce efficiency scores. Furthermore, universities are bordered between zero and one scores with completely efficient universities having an efficiency score of one. In DEA, the most efficient university (with score of one) does not necessarily generate the maximum level of output from the given inputs. Rather, such a university generates the best practice level of output among other universities in the sample. The term DEA, was introduced by Charnes, Cooper and Rhodes (CCR) (1978) based on Farrell's (1957) research.

According to Seiford and Thrall (1990), the Data Envelopment Analysis (DEA) is also a non-parametric method which extends efficiency measures from a single input and single output efficiency analysis to multi-input and multi-output situations. In DEA, the efficiency of a Decision-Making Unit (DMU) is measured relative to all other DMUs with a simple restriction that all DMU lie on or below efficient frontiers.

DEA has two major advantages. First, it can handle multi-dimensional problems with multiple input and output indices (variables). This feature makes DEA an advantageous performance evaluation tool widely adopted in various fields. Second, DEA avoids the difficulty of deciding for potentially unequal weights for the criteria. In Multi-Criteria Decision Making (MCDM) problems, the allocation of weights (to show the varying importance levels for criteria) is generally controversial. DEA uses the weight for each input and output that will let each DMU reach its maximum possible efficiency value (Charnes, Cooper, Lewin and Seiford, 1994). One of the most important features of DEA is the ability to compare many parameters simultaneously and come up with a scalar measure of overall performance. DEA provides the relative efficiency of each of the organization in a given set of other organizations. These DMUs are assumed to be in the business of producing various output by consuming a set of inputs. In general, several inputs are required to produce one or more output for an organization (Saranga and Phani, 2004).

The vast majority of efficiency analyses for higher educational institutions have employed data envelopment techniques (Kempkes and Pohl, 2008). Due to the fact that universities are producers of at least two output - teaching and research, DEA seems to be an appropriate method.

\subsection{Studies on the use of DEA in universities}

Initial studies were conducted for universities in Anglo-Saxon countries. Johnes and Johnes (1993) performed a crosssectional investigation on the efficiency of Economics department in 36 British universities in the year 1989. Beasely (1997) also considered a single year (1992) to study the relative efficiency of Chemistry and Physics departments of 32 British universities. Madden, Savage and Kempkes (1997) used panel data in order to evaluate the efficiency of Economies departments in Australian universities.

More recent studies have focused on evaluating entire universities since they are often associated with the availability of panel data in the first place, which in turn permits a study of efficiency change over time. Athanassapoulos and Shale (1997) analysed the relative efficiency of 45 British universities for the years 1992/1993 indicating that there are significant differences across higher educational institutions. Abbott and Doucouliagos (2003) considered 36 Australian public universities in their investigation. Flegg, Allen, Field and Thurlow (2004) used data envelopment 
analysis to examine changes in technical efficiencies of 45 British universities in the period 1981-1993.

Breu and Raab (1994) applied the DEA to measure relative efficiency of the top 25 universities in the United States. They found that the most prestigious universities always generated a high level of satisfaction among students. The authors finally concluded by suggesting that university expenditures should be timed more at increasing levels of efficiency rather than in improving perceived quality. Johnes (2006) made an analysis based on a data set consisting of 2547 graduates in 1993 from British universities' faculties of Economics in order to evaluate efficiency.

Studies also made a comparison between university systems of different countries. Note that in cases of crosscountry analyses, problems may arise. They are related to the difficulty in obtaining comparable data between the different countries considered which eventually limits the scope of investigation (Salerno, 2003). Jouimady and Ris (2005), in a survey, carried out a comparison between the universities of different countries based on responses from young graduates. Analysis estimated efficiency of 209 universities belonging to 8 European countries.

Another comparative work was carried out by Agasisti and Johnes (2009) with a focus on the university technical efficiency in Italy and the United Kingdom. The emerging results for that study appear to demonstrate that British universities are more efficient than their Italian counterparts. A similar study was conducted by Agasisti and PerezEsparrells in 2010, this time on Italian and Spanish universities. Basing the analysis on 'country-specific' frontier, each of the two countries has a good average efficiency in higher education. However, in terms of comparison, Italian universities seem relatively more efficient than the Spanish ones.

\subsection{DEA conceptual input-output framework of universities}

Based on a number of studies, teaching and research inputs could include:the number of undergraduate or doctoral students (Ahn and Seiford, 1993; Athanassopoulus and Shale, 1997; Hanke and Leopoldseder, 1998; Garcia-Aracil, 2006); academic and non-academic staff (Van de Panne, 1991); staff costs (Ahn, Charnes and Cooper, 1988; Hanke and Leopoklseder, 1998); total expenditure (Ahn et al, 1988); research and development expenditure (Ahn, 1987); capital expenses, library expenses, computer services and structures (Ahn et al 1988); and space cost (Bessent and Bessent, 1980).

On the other hand, the output measures as earlier stated, which accurately reflect the roles, function and performance of a university are teaching, research and community service. As prescribed by Coelli, Prasada and Battesse (2000), the following output measures are considered with regards to teaching: the number of students; the number of students in different disciplines - in social sciences, sciences, medicine and engineering; the number of undergraduate and postgraduate students; and the number of weighted full-time equivalent students by discipline and level.

Similarly, Ana and Edgar (2002) identified the following as teaching indicators: the number of recipients of Bachelor, Master and Doctoral degrees granted by the university. They equally stated the following as: the number of research publications: the number of books, book chapters, journal articles, conference papers and other scholarly publications; the number of weighted research publications: each publication is weighted depending on whether it is a book, a chapter or a journal article - it is necessary to specify some weights in constructing this measure; quality of research publication.

In terms of community service, the researchers also identified the following indicators: the number of social assistance registered in the academic planning unit of the university; the number of cultural activities registered in the academic planning unit of the university; the number of scientific meetings (national or international) and conferences organized by the university; the number of consultant activities delivered to private firms; the number of courses delivered to the local community; the number of seminars, lectures and symposia delivered to the local community; the number of technical services delivered to the local community; and the number of student scholarships granted to extension projects developed by the university.

\section{Methodology}

This study adopted the ex post facto and longitudinal research design. The choice was premised on the non-controllability and non-manipulability of university input and output as well as the time frame of $2006-2010$.

From a total number of 37 federal universities, 17 was identified as sample size. These are fully established, nonspecialized universities. The universities of science and technology, agriculture, petroleum resources, defense academy, open university, police academy considered to be specialized universities could not be selected for the study due to the one -track nature of their mandate. They number eleven (11). In addition, nine (9) newly established federal universities 
considered not to be fully developed were equally not selected for the study. Sufficient wide-spreadand in-depth information could not be provided by these universities. Besides, the newly established universities do not fall within the period (2006-2010) under the study.

The 17 federal universities used in this study are University of Ibadan (IBADAN), University of Nigeria (NSUKKA), Obafemi Awolowo University (ILE-IFE), Ahmadu Bello University (ZARIA), University of Lagos (LAGOS), University of Benin (BENIN), Bayero University (KANO), University of Calabar (CALABAR), University of llorin (ILORIN), University of Jos (JOS), University of Maiduguri (MAIDUGURI), University of Sokoto (SOKOTO), University of Port Harcourt (P/HARCOURT), University of Abuja (ABUJA), Nnamdi Azikiwe University (AWKA), University of Uyo (UYO) and University of Bauchi (BAUCHI).

Secondary sourced data were used for the study. These were provided by the National Universities Commission (NUC) through its records as well as website. The data were considered very useful and appropriate for the study.

\subsection{Model specification and data analyses plan}

The study was subjected to the DEA model focused on measuring federal universities performance efficiency. In it, the DEA input-oriented CCR model was used. The CCR model refers to the formulation developed by Charnes, Cooper and Rhodes (CCR) (1978) uses linear programming to extend Farrell's (1957) single output/single input efficiency measures to the multi-output/multi input case. The focus is to optimize the ratio of outputs to inputs by solving for a group of weights that satisfy a system of linear equations (Rouse, 1997). The formular is indicated hereunder.

Maximize $\emptyset_{i}$

$\emptyset_{i} \lambda_{j}$

Subject to:

$\emptyset_{i y_{r j}}-\Sigma \lambda_{r j}+S_{r i}=0$

$n$

$r=1, \ldots s$ output of federal universities

$j=1$

$x_{k i}-\sum \lambda_{j} X_{k j}-e_{k i}=0$

$n$

$\mathrm{k}=1, \ldots, \mathrm{m}$ input of federal universities

$\lambda_{j} \geq 0, S_{r i} \geq 0, e_{k i} \geq 0$

$j=1$

$\mathrm{i}, \mathrm{j}=1, \ldots . \mathrm{n}$ federal universities in the sample

where:

$\varnothing=$ proportional increase in outputs possible:

$S_{r}=$ r-th output slack;

$e_{k}=$ k-th input slack;

$\lambda_{j}=$ weight or intensity variable used to derive all possible linear combinations of the sample observations.

When the value of $\emptyset_{i}$, in equation (1) is 1 ,

$\lambda_{i}=1$, and

$\lambda_{i}=0$ for $\mathrm{j} \neq \mathrm{i}$,

the i-th federal university lies on the frontier and is technically efficient.

Furthermore, input and output slacks will always be zero for the efficient federal universities. For the inefficient universities, $\emptyset_{i}>1, \lambda_{i}=0$, and $\lambda_{j} \neq 0$ for $j \neq 1$, where $j$ denotes the efficient federal universities in the sample. Inefficient federal universities may also have some positive output or/and input slacks. The output based technical efficiency index of the i-th federal universities $\left(T e_{j}\right)$ can be computed as follows:

$$
T e_{j}=\frac{1}{\emptyset_{i}}
$$

The frontier production of the r-th output of the i-th federal university can be computed as follows:

$n$

$y_{r i}=\sum \lambda_{i j} y_{r i}=\emptyset_{i j} y_{r i}+S_{r i}$

Equation (6) shows that the projected output consists of two components, one representing the proportional $j=1$ 
increase in all output $\left(\emptyset_{i} y_{r i}\right)$ and the other accounting for the non-proportional increase or output slack $\left(S_{r}\right)$. Besides estimating the maximum output from fixed inputs, the output-oriented DEA in equation (1) also estimates the input slacks (excess inputs) that need to be conserved for an inefficient federal university to be fully efficient. Mathematically, the projected amount of the $k$-th resource of the i-th federal university $\left(x_{k i}\right)$ can be expressed as follows:

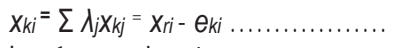

$\mathrm{k}=1, \ldots \mathrm{m}$ input

It should be noted that the federal universities DEA model given in equation (1) implies the Constant Returns to Scale (CRS) technology. Following Banker, Charnes, and Cooper (1984), the corresponding model under Variable Returns to the Scale (VRS) can be obtained by imposing an additional constraint, $\Sigma_{j=1} \lambda_{j}=1$ on equation (3). The technical efficiency score obtained from the CRS model (TE $\left.E_{C R S}\right)$ is often referred to as "overall" technical efficiency and that obtained from the VRS model is called "pure" technical efficiency (TEVRS). The VRS frontier is more flexible and envelops the data in a tighter way than the CRS frontier. Under the VRS specification, dominance is weaker in the sense that a scale inefficient federal university may qualify as a 'best-practice' if it is technically efficient. Consequently, in general, federal universities will show a poorer performance under the CRS model than in the VRS model (i.e., TEvRS $\geq$ $\left.T E_{C R S} \Leftrightarrow \emptyset_{C R S} \geq \varnothing_{V R S}\right)$. This relationship is often used to obtain a measure of scale efficiency (SE) as follows:

$$
S E=\underline{T e} \underline{C R S}=\emptyset_{V R S}
$$

TevRS $\emptyset_{C R S}$

where SE = 1 indicates scale efficiency and SE $<1$ indicates output-based scale inefficiency. Scale inefficiency is due to the presence of either Increasing Return to Scale (IRS) or Decreasing Returns to Scale (DRS) which can be determined by solving a Non-Increasing Returns to Scale (NIRS) DEA model which is obtained by substituting the VRS constraint $\Sigma_{j=1} \lambda_{j}=1$ with $\sum_{j=1} \lambda_{j} \leq 1$.

Let $\emptyset_{\text {NIRS }}$ represent the proportional increase in all outputs under the NIRS DEA model. For scale inefficient observations, $\varnothing_{C R S}=\varnothing_{\text {NIRS }}$ indicates inefficiently small scale or operation in the region of increasing returns to scale and $\emptyset_{C R S}=\emptyset_{\text {NIRS }}$ indicates inefficiency large scale or decreasing returns to scale (Fare, Grosskopf and Lovell, 1994). This study will make use of the scale efficiency results in measuring the performance efficiency of the universities.

\subsection{DEA Data}

This study made use of six inputs and four outputs to measure the relative performance efficiency of the selected 17 federal universities in Nigeria. These are indicated in Table 1

Table 1: University Input and Output Indicators

\begin{tabular}{|l|l|}
\hline University Input & University Output \\
\hline Number of academic staff; & Number of graduating undergraduate students; \\
Number of non-academic staff; & Number of graduating Postgraduate Diploma students; \\
Number of admitted undergraduate students; & Number of graduating Masters students; \\
Number of admitted postgraduate students; & Number of graduating Doctorate students. \\
Capital Grants; & \\
Recurrent Grants. & \\
\hline
\end{tabular}




\subsection{Results}

The tabular analysis of the results is indicated in table 2 below

Table 2: Scale efficiency scores of the 17 Nigerian Federal Universities based on DEA model

\begin{tabular}{|c|c|c|c|c|c|c|}
\hline DMU No & Universities & $\begin{array}{c}\text { CRS/VRS } \\
\mathbf{2 0 0 6}\end{array}$ & $\begin{array}{c}\text { CRS/VRS } \\
\mathbf{2 0 0 7}\end{array}$ & $\begin{array}{c}\text { CRS/VRS } \\
\mathbf{2 0 0 8}\end{array}$ & $\begin{array}{c}\text { CRS/VRS } \\
\mathbf{2 0 0 9}\end{array}$ & $\begin{array}{c}\text { CRS/VRS } \\
\mathbf{2 0 1 0}\end{array}$ \\
\hline 1 & IBADAN & 0.46806 & 0.94456 & 1.00000 & 0.94943 & 1.00000 \\
\hline 2 & ILE-IFE & 0.54209 & 0.99103 & 0.98911 & 0.86169 & 0.91211 \\
\hline 3 & NSUKKA & 0.68286 & 0.90559 & 0.83077 & 0.89787 & 1.00000 \\
\hline 4 & ZARIA & 0.64431 & 0.99231 & 0.96407 & 0.71650 & 0.98714 \\
\hline 5 & LAGOS & 1.00000 & 0.97824 & 0.99878 & 0.99951 & 1.00000 \\
\hline 6 & BENIN & 0.79064 & 1.00000 & 1.00000 & 1.00000 & 1.00000 \\
\hline 7 & KANO & 1.000000 & 1.00000 & 1.00000 & 1.00000 & 1.00000 \\
\hline 8 & CALABAR & 0.87880 & 1.00000 & 1.00000 & 1.00000 & 1.00000 \\
\hline 9 & ILORIN & 0.85388 & 0.97501 & 1.00000 & 0.99712 & 1.00000 \\
\hline 10 & JOS & 0.27816 & 0.75267 & 0.50573 & 0.36767 & 1.00000 \\
\hline 11 & MAIDUGURI & 1.00000 & 1.00000 & 1.00000 & 1.00000 & 1.00000 \\
\hline 12 & SOKOTO & 0.86198 & 0.94361 & 0.95334 & 1.00000 & 1.00000 \\
\hline 13 & P/HARCOURT & 0.93824 & 0.95796 & 0.94816 & 1.00000 & 1.00000 \\
\hline 14 & ABUJA & 1.00000 & 1.00000 & 1.00000 & 1.00000 & 1.00000 \\
\hline 15 & AWKA & 1.00000 & 1.00000 & 1.00000 & 1.00000 & 1.00000 \\
\hline 16 & UYO & 1.00000 & 1.00000 & 0.87383 & 0.77256 & 1.00000 \\
\hline 17 & BAUCHI & 0.50777 & 0.77781 & 0.80015 & 0.95131 & 1.00000 \\
\hline
\end{tabular}

Source: Survey (2012).

Table 2 revealed that on the basis of a scale efficiency scores (TEcrs/TEvrs) only four (4) federal universities out of the 17 selected universities were scale efficient while the rest were found to be scale inefficient for the period (2006-2010) under study. The four (4) scale efficient universities that were able to use their input to generate higher graduate outputs under both VRS and CRS DEA assumptions for over the period are; Bayero University (KANO), University of Maiduguri (MAIDUGURI), University of Abuja (ABUJA), and Nnamdi Azikiwe University (AWKA). This means that their management was successful in converting input to output and they also utilized a better scale of operation for the 5 years period of the study. The table equally revealed that the universities of Benin and Calabar were relatively scale efficient but for only four years out of the five years period.

The study discovered that overall technical efficiency (CRS DEA model) is based on relative efficiency in terms of using the right scale of operation without consideration for managerial skill while the pure technical efficiency (VRS DEA model) shows the success of universities management at input to output "conversion". The scale efficiency which is the ratio of overall technical efficiency (TEcrs) to pure technical efficiency (TEvrs) measures how much a university can improve its efficiency by being projected from VRS to CRS, that is the ability of further increasing its outputs radically. It reflects the efficiency of the universities irrespective of whether it operates at the right returns to scale or not. For a university to become scale efficient it should increase its output further to reach the most productive scale size.

On the basis of the analysed results, the universities of Maiduguri and Abuja as well as Bayero University (KANO) and Nnamdi Azikiwe University (AWKA) are efficient and as such considered as an appropriate benchmark for other universities. This implies that only $25 \%$ of our sampled universities are efficient. The results show that universities of Maiduguri, Abuja, Bayero Kano and Nnamdi Azikiwe Awka had 0.0000 as slack in their inputs in most years. This implies that they fully utilized all resources allocated to them. The indication therefore is that out of 17 federal universities, only four (4) representing $23.5 \%$ are efficient in the SCALE models. The implication is that these universities adequately utilized their inputs in the production of large number of graduates (output). In contrast, however, the old universities such as university of Ibadan, Ahmadu Bello university, Zaria and Obafemi Awolowo university have the best physical facilities in terms of buildings and space are not able to perform efficiently. 


\section{Conclusion}

This study so far reveals that the DEA techniques is useful in measuring performance efficiency of Nigerian federal universities. Our findings from the research indicate that only 4 out of 17 federal universities studied were performing efficiently. And these universities are Maiduguri, Abuja, Kano and Awka. Our plausible conclusion is that these universities should serve as benchmark for other universities. In addition, our instrument, the DEA technique appear useful for decision making units or organizations particularly in Nigeria. It is therefore recommended that all universities in Nigeria, especially federal universities should understudy AWKA, MAIDUGURI, KANO and ABUJA so as to learn from them and ensure that they too are becoming efficient in managing their resources. These efficient universities have efficiency scores of 1 which implies that they have successfullyand strategically managed and utilized all the resources available to them. No input was left idle or underutilized.

\section{A Glossary Of Abbreviations Of Terms/Names}

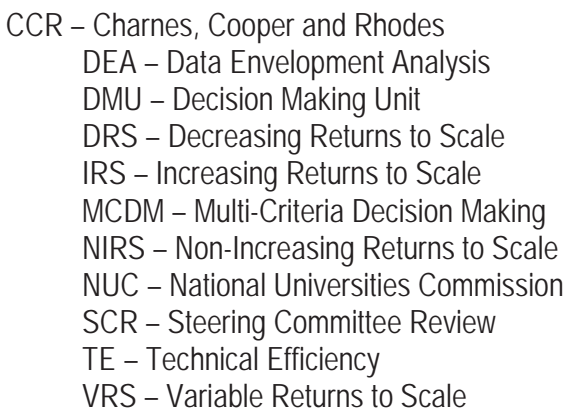

\section{References}

Abbot, M. \& Doucouliagos, C. (2003). The efficiency of Australian university: A Data Envelopment Analysis. Economics of Education Review, 22(1), 89-97.

Abdulkareem, A.Y \& Oyeniran, S. (2011). Managing the performance of Nigeria universities for suitable development using data envelopment analysis. International Journal of Academic Research in Business and Social Science, 15(1), 54-67.

Agasisti, T. \& Johnes, G. (2009). Comparing the efficiency of higher education decision making units across more than one country. Education Economics, 17, 59-79

Ahn, T., Charnes A., Cooper W. (1988). Some statistical and DEA evaluations of relative efficiencies of public and private institutions of higher learning. Socio-economicsPlanning Sciences, 22(6), 259-269.

Ahn, T. \& Seiford, L.W. (1993). Sensitivity of LEA to models and variable sets in a hypothesis test setting: The efficiency of university operations. In ljiri, (ed.). Creative and Innovative Approaches to the Science of Management, Westport, CT: Quorum Book.

Ahn, T. (1987). Efficiency and related issues in higher education: A Data Envelopment Analysis approach. Graduate School of Business, Texas University.

Ana, L.M. \& Edgar, A.L. (2002). Data envelopment analysis (DEA) and fuzzy set to assess the performance of academic departments: A case study at federal university of Santa Catarina. Pesquisa Operational, 22(2), 217-230.

Athanassopoulos, A.D. \& Shale, E. (1997). Assessing the comparative efficiency of higher education institutions in the UK by means of data envelopment analysis. Education Economics, 5, 117-134.

Australian Government Productivity Commission (2009). Contribution of the not-for-profit sector. Retrieved March 12, 2013, from http://www.pc.gov.au/projects/study/not-for-profit/draft.

Banker,B.D, Charnes, R.F \& Cooper, W.W. (1984). Some models for estimating technical and scale inefficiencies in data envelopment analysis. Management Science, 30,1078-1092.

Beasley, J. (1997). Determining teaching and research efficiencies. Journal of Operational Research Society, 1111, 441-452.

Bessent, A.M. \& Bessent, E.W. (1980). Determining the comparative efficiency of schools through data envelopment analysis. Educational Administration Quarterly, 16(2), 57-75.

Breu, T.M. \& Raab, R.L., (1994). Efficiency and perceived quality of the nation's Top 25 national universities and national liberal arts colleges: An application DEA to higher education. Socio-Economic Planning Sciences, 28(1), 35-45.

Bowlin, W.F. (1998). Measuring performance: An introduction to data envelopment analysis (DEA). Journal of Cost Analysis, 8, 3-27.

Burger, F. (2008). Impact measurement as a means to improve the accountability of non-profit organizations. An impact measurement study of the Netherlands Heart Foundation on the burden of disease of AMI-patients. A thesis submitted to the Department of Applied Economics, Erasmus University, Rotterdam. 
Charnes A., Cooper, W. Lewin A., \& Seiford, L. (1994). Data envelopment analysis: theory, methodology and application. Boston, MA: Kluwer Academic Publishers.

Charnes A., Cooper, W. W. \& Rhodes, E. (1978). Measuring the efficiency of decision making units. European Journal of Operations Research, 2:429-444.

Coelli, T. \& Perelman, S. (1990). A comparison of parametric and non-parametric distant functions and application to European railways. European Journal of Operation Research, 117, 326-339.

Coelli, T., Prasada, R.T.D. \& Battesse, G.E. (2000). An introduction to efficiency and productivity analysis. USA: Springer International Series.

Coelli, T. (1992). Assessing the performance of Australian universities using data envelopment analysis. Internal report, center for efficiency and productivity analysis, University of New England.

Fare, R.S., Grosskopf, S. \& Lovell, C.A.K. (1994). Production frontiers. Cambridge university press.

Farrell, M.J. (1957). The measurement of productive efficiency. Journal of Royal Statistics Society, 120 (Part III): 253-281.

Flegg, A., Allen, D.O. Field, K. \& Thurlow, T.W. (2004). Measuring the efficiency of British universities: A multi-period data envelopment analysis. Education Economics 12(3), 231-249.

Garcia-Aracil, A. \& Palomares-Montero, D. (2008). Evaluation of Spanish universities: efficiency, technology and productivity change. A Paper Presented in the Prime-Latin America Conference at Mexico City, September 24-26, 2008.

Garcia-Aracil, A. (2006). Overview of regional differences in the Spanish higher education system, in Bonaccorsi, A. \& Cinzia, D. (eds.) Universities and Strategic Knowledge Creation. UK: Edward Elgar,

Agasisti, T. \& Johnes, G. (2009). Comparing the efficiency of higher education decision making units across more than one country. Education Economics, 17, 59-79.

Hannula M., Kulamala, H.I., \& Suomala, P. (1999). Total quality management and balanced scorecard -A comparative analysis. In W. Werther, Jr. et al. (Ed.), Productivity \& quality management frontiers - VIII, 633-648. Bradford, UK: MCB University Press.

Hsu, C.W. \& Liu, H.Y. (2008). Corporate diversification and company performance: the moderating role of contractual manufacturing model. Asia Pacific Management Review, 13(1), 345-360.

Igbinosa, B.O. (2008). Measuring the relative efficiency of Nigerian universities: A data envelopment analysis (DEA) approach. A Ph.D Dissertation submitted to the Department of Business Administration, University of Benin.

James E. (1990). Decision processes and priorities in higher education. In S.A. Hoenack and E.I. Collins (Eds.), The Economics of American Universities. Buffalo, Ny: State University of New York Press.

Johnes J. (2006). Data envelopment analysis and its applications to the measurement of efficiency in higher education. Economics of Education Review. 25(3), 273-288.

Johnes, G. \& Johnes, J. (1993). Measuring the research performance of UK economics departments: application of data envelopment analysis. Oxford Economic Papers, 45, 332-348.

Jouimady, O. \& Ris. C. (2005). Performance in European higher education: a non-parametric production frontier approach. Education Economics, 13(2), 189-205.

Joshi, R. N. \& Singh, S. P. (2009). Measuring production efficiency of readymade garment firms. Journal of Textile and Apparrel, Technology and Management, 6(2), 1-12.

Kempkes, G. \& Pohl, C. (2008). The efficiency of German universities: Some evidence from non-parametric methods. Applied Economics. On-Line First.

Lindenberg, M. (2001). Are we at the cutting edge or the blunt edge? Improving NGO organizational performance with private and public sector strategic management frameworks. Nonprofit Management \& Leadership, 11(3), 247-270.

Madden G., Savage S. \& Kemp, S. (1997). Measuring public sector efficiency: A study of the Economics Department at Australian universities. Education Economics, 5(2), 153-168.

Modell, S. (2005). Performance management in the public sector: past experiences, current practices and future challenges. Australian Accounting Review, 15(3), 56-66.

Ponnu, C.H. \& Ramthandin, S. (2008). Governance and performance: publicly listed companies in Malaysia. Journal of Business Systems, Governance and Ethics, 3(1), 35-53.

Popoola, A., Oyinloye, G. \& Oginni, O.I. (2011). Performance measure and job constraints: implications for women in academics in Nigeria universities. International Journal for Cross-Disciplinary Subjects in Education (IJCDSE), Special Issue (1), 596600.

Radam, A.M.L. \& Abdullahi, A.M. (2008). Technical efficiency of small and medium enterprise in Malaysia: a stochastic frontier production model. International Journal of Economics and Management, 2(2), 395-408.

Rouse, P. (1997). A methodology of performance measurement with applications using data envelopment analysis. Unpublished PhD Thesis. The University of Auckland Library, Auckland.

Salerno, C. (2003). What we know about the efficiency of higher education institutions: the best evidence. The centre for Higher Education Policy Studies, University of Twenty.

Saranga, H. \& Phani, B.V. (2004). The Indian pharmaceutical industry-an overview of internal efficiencies using data envelopment analysis. Indian Institute of Management Calcutta. (WPS-495).

Saunders, M. Lewis, P \& Thornhill, A. (2003). Research methods for business student. Harlow: Prentice Hall.

Seiford, L.M. \& Thrall, R.M. (1990). Recent development in DEA: The mathematical programming approach to frontier analysis. Journal of economics, $A(46-11-2)$ 
The Steering Committee for the Review of Commonwealth/State Service Provision. (1997),Data envelopment analysis: A technique for measuring the efficiency of government service delivery. Canberra, Australia.

Thanassoulis, E. (2001). Introduction to the theory and application of data envelopment analysis: a foundation text with integrated software. Norwell, MA: Kluwer Academic Publishers.

Thore, S., Kozmetsky, G. \& Philips, F. (1994). DEA of financial statements data: the U.S. computer industry. The Journal of Productivity Analysis, 5, 229-248.

Utulu, S. (2007). Webometric ranking and Nigerian private universities: a case study of Bells university of technology, Ota, available at: www.ro20ar/paperlandia/detaile.php/id handler=8198.

Agasisti, T. \& Johnes, G. (2009). Comparing the efficiency of higher education decision making units across more than one country. Education Economics, 17, 59-79.

Warning, S. (2004). Performance differences in German higher education: empirical analysis of strategic group. Review of Industrial Organization, 24, 393-408.

Warning, S. (2005). Eczienz deutscher Hochschulen: Gibt es regionale Unterschiede"?, in Bil-dungsokonomische Analyse mit Milkrodaten, Bellmann, L. and D. Sadowski, 65-81.

Wright, W. F., Smith, R., Jesser, R., \& Stupeck, M. (1999). Information technology, process reengineering and performance measurement:a balanced scorecard analysis of compaq computer corporation. Communications of the Association for Information Systems, 1. Retrieved May 12, 2004, from http//fag.hia.no/kurs/is/is4400/artickler/wright_etal.htm

Wu, C.C., Kao, S.C. \& Cheng., H.H. (2006). Examining retailing performance via financial index. Asia Pacific Management Review. 11(2), 83-92.

Wu, H.L. (2005). A DEA Approach to understanding the performance of Taiwan's steel industries 1970-1996. Asia Pacific Management Review, 10,349-356.

Yates, H., (2004). The impact of impact assessment: the experience of rural voluntary and community organizations and evaluating change. London: NCVO Publications. 